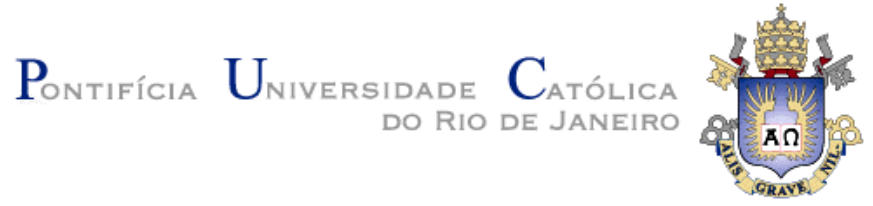

Felipe Bó Huthmacher

\title{
A linguagem entre o devir e a alienação
}

\section{Dissertação de Mestrado}

Dissertação apresentada ao Programa de Pós graduação em Psicologia Clínica da PUC-Rio como requisito parcial para obtenção do título de Mestre.

Orientador: Prof. Carlos Augusto Peixoto Junior

Rio de Janeiro, fevereiro de 2011. 


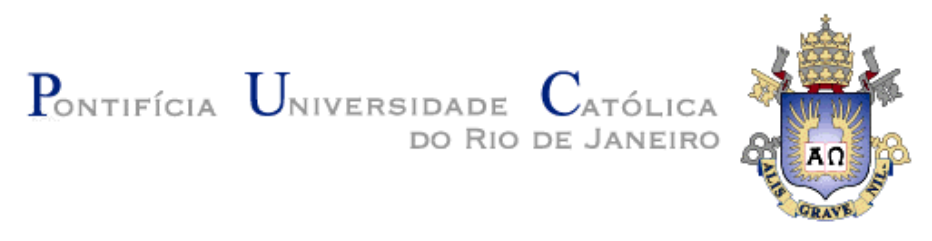

Felipe Bó Huthmacher

\title{
A linguagem entre o devir e a alienação
}

Dissertação apresentada como requisito parcial para obtenção do grau de Mestre pelo Programa de PósGraduação em Psicologia Clínica do Departamento de Psicologia do Centro de Teologia e Ciências Humanas da PUC-Rio. Aprovada pela Comissão Examinadora abaixo assinada.

\author{
Prof. Carlos Augusto Peixoto Junior \\ Orientador \\ Departamento de Psicologia - PUC-Rio
}

Prof. Auterives Maciel Junior Departamento de Psicologia - PUC-Rio

Prof. André Martins Vilar de Carvalho Inst. de Filosofia e Ciências Sociais - UFRJ

Profa. Denise Berruezo Portinari Coordenadora Setorial de Pós-Graduação

e Pesquisa do Centro de Teologia e Ciências Humanas - PUC-Rio

Rio de Janeiro, 23 de fevereiro de 2011. 
Todos os direitos reservados. É proibida a reprodução total ou parcial do trabalho sem autorização do autor, do orientador e da universidade.

\section{Felipe Bó Huthmacher}

Graduou-se em Psicologia na PUC-Rio em 2008. Defendeu a sua Dissertação de Mestrado em Psicologia Clínica no Departamento de Psicologia da PUC-Rio em fevereiro de 2011. Desenvolve pesquisas que buscam viabilizar o diálogo entre a teoria psicanalítica e o campo da filosofia.

Ficha Catalográfica

Huthmacher, Felipe Bó

A linguagem entre o devir e a alienação / Felipe Bó Huthmacher; orientador: Carlos Augusto Peixoto Junior. - 2011. $103 \mathrm{f}$; ; $30 \mathrm{~cm}$

Dissertação (mestrado) - Pontifícia Universidade Católica do Rio de Janeiro, Departamento de Psicologia, 2011.

Inclui bibliografia

1. Psicologia - Teses. 2. Inconsciente. 3. Linguagem. 4. Devir. 5. Experiência trágica. 6. Alienação do significante. I. Peixoto Junior, Carlos Augusto. II. Pontifícia Universidade Católica do Rio de Janeiro. Departamento de Psicologia. III. Título.

CDD: 150 


\section{Agradecimentos}

A Carlos Augusto Peixoto Junior, por me convidar a desenvolver a monografia da gradução e pelos 5 anos de parceria.

A Fabio Araújo, pelo esforço no sentido de esquizofrenizar o mundo; a todos os Vagabundos Iluminados de segunda-feira à noite.

A Pedro, Conrado, Danilo, Gilberto, Ana Thereza, Arthur e Natasha: interlocutores geniais, amizades singulares.

A João Manuel e a idéia de um ambiente ideal.

Aos meus pais e aos meus irmãos, que não me deixaram morrer de solidão.

A Isabel Fortes, abolicionista praticante.

Ao CNPq e à PUC-Rio, por tornarem essa dissertação possível. 


\section{Resumo}

Huthmacher, Felipe Bó; Peixoto Junior, Carlos Augusto (orientador). A linguagem entre o devir e a alienação. Rio de Janeiro, 2011. 103p. Dissertação de Mestrado Departamento de Psicologia, Pontifícia Universidade Católica do Rio de Janeiro.

O presente trabalho trata das relações estabelecidas entre as concepções de inconsciente e linguagem nas obras de Nietzsche, Lacan, Deleuze e Guattari. No final do século XIX, ocupando-se do papel da estética trágica na cultura da Grécia Antiga, Nietzsche enxerga na arte de Sófocles e Ésquilo um universo simbólico em harmonia com as pulsões inconscientes da vida. Ao mesmo tempo, diagnostica na atitude socráticoplatônico-cristã uma interrupção dos processos em devir simbolizados pela linguagem trágica em nome de uma apologia às virtudes dialéticas da consciência e à negatividade de um monoteísmo antropocêntrico. Lacan, na década de 1950, surge como uma alegoria desse modo negativo de se relacionar com os processos inconscientes da linguagem, ao passo que Deleuze e Guattari, também na segunda metade do século XX, afirmam a experiência trágica da análise nietzschiana como forma de explodir as estruturas lacanianas que cerceiam a vida submetendo o desejo ao monoteísmo-dialético próprio à alienação do significante.

\section{Palavras-chave}

Inconsciente; linguagem; devir; experiência trágica; alienação do significante. 


\section{Abstract}

Huthmacher, Felipe Bó; Peixoto Junior, Carlos Augusto (advisor). The language between the becoming and the alienation. Rio de Janeiro, 2011. 103p. MSc Dissertation - Departamento de Psicologia, Pontifícia Universidade Católica do Rio de Janeiro.

This work deals with the relations established between the concepts of the language and of the unconscious in the works of Nietzsche, Lacan, Deleuze and Guattari. In the late nineteenth century, taking care of the role of tragic aesthetics in the culture of Ancient Greece, Nietzsche sees on the art of Sophocles and Aeschylus a symbolic universe in harmony with the unconscious drives of life. At the same time, he diagnoses the attitude socratic-platonic-christian as an interruption of the becoming processes symbolized by the tragic language on behalf of an apology to the virtues of a dialectical consciousness and the negativity of an anthropocentric monotheism. Lacan, in the 1950s, emerges as an allegory of this negative way of dealing with the unconscious processes of language, while Deleuze and Guattari, also in the second half of the twentieth century, affirm the nietzschian analysis of the tragic experience state as a way to blow up the lacanian structures that curtail life by the submission of desire on a monotheism-dialectic to the itself significant alienation.

\section{Keywords}

Unconscious; language; becoming; tragic experience; significant alienation. 


\section{Sumário}

$\begin{array}{lr}\text { Introdução } & 8\end{array}$

1. Linguagem e experiência trágica em Nietzsche 11

1.1. O inconsciente e o instinto na origem da linguagem 11

1.2. A linguagem da tragédia grega 13

1.3. O Eurípides dialético e a influência de Sócrates 17

1.4. Fisiologia das linguagens morais $\quad 21$

1.5. Etimologia e moral escrava $\quad 26$

1.6. Denominação e niilismo $\quad 29$

1.7. Zaratustra: metamorfose e superação 32

2. Lacan e a alienação do significante 37

2.1. O inconsciente linguistico $\quad 37$

2.2. O escravo dialético $\quad 42$

2.3. O Outro platônico

2.4. O Nome-do-Pai e a colonização do desejo 51

2.5. A carta e o falo 58

3. Deleuze \& Guattari: linguagem e devir 66

3.1. Jaques e Gilles 66

$\begin{array}{ll}3.2 \text { O paradoxo do falo } & 70\end{array}$

3.3 Félix e suas máquinas $\quad 76$

3.4. O déspota despedaçado $\quad 82$

3.5. O devir das línguas 88

3.6. Kafka e a intensidade menor 95

4. Conclusão 99

5. Referências Bibliográficas 101 